\title{
Efficient priority rules under default: the case of traditio versus contract principle
}

\author{
Jens Andreasson ${ }^{1}$. Wolfgang Faber ${ }^{2} \cdot$ Shubhashis Gangopadhyay ${ }^{1,3,4,5}$. \\ Claes Martinson ${ }^{1} \cdot$ Stefan Sjögren $^{1}$ (i)
}

Published online: 24 September 2020

(c) The Author(s) 2020

\begin{abstract}
We investigate the economic consequences of the traditio and the contract principle-differing in how they determine the priority rights for an item sold but not delivered. Our results suggest that the two principles are equivalent in terms of the net utilities enjoyed by involved actors. For example, a lower price paid for a forward transaction under a traditio principle can be compensated by better credit terms, implying there is no competitive advantage for either the seller or buyer under any principle. We demonstrate how market prices, incorrectly used, may misleadingly favour a contract principle, and discuss how fraudulent behaviour better supports a traditio regime. We also contribute to the legal discussion on priority regimes of undelivered items basing our discussion on bankruptcy priority laws instead of distribution of ownership.
\end{abstract}

Keywords Priority rules · Bankruptcy · Traditio principle $\cdot$ Delivery model · Transfer of ownership

JEL Classification $\mathrm{G} 33 \cdot \mathrm{K} 20 \cdot \mathrm{K} 00 \cdot \mathrm{L} 50$

Stefan Sjögren

stefan.sjogren@handels.gu.se

1 School of Business, Economics and Law, University of Gothenburg, Gothenburg, Sweden

2 University of Salzburg, Salzburg, Austria

3 India Development Foundation, Gurugram, India

4 University of Groningen, Groningen, The Netherlands

5 Indian School of Public Policy, New Delhi, India 


\section{Introduction}

This study investigates the economic consequences of two opposing legal principles that may be applied by legislators to determine the priority rights of various parties when a business becomes insolvent. Our focus is on a case involving advance purchases, where an item has been paid for but due to the seller's bankruptcy is not delivered. In such cases, the firm's (or, seller's) bankruptcy proceedings begin before they make the delivery, thus hindering the delivery despite the customer having already paid the agreed-upon price while the seller was still solvent. In this situation, the legislators must determine the party that takes priority over the undelivered item-the seller's creditor(s) or the customer. The legal variant of this problem has been debated among lawyers within different jurisdictions.

Under the contract principle (also called the consensus principle), the buyer is given priority over the seller's other creditors. ${ }^{1}$ Since there is a valid contract, and provided the item is specified, the bankruptcy estate must give the buyer priority for the item. In this case, the item is not considered part of the bankruptcy estate. Conversely, under the 'traditio' principle (also called the delivery principle) the buyer is protected only if the delivery has already happened. ${ }^{2}$ If the delivery has not been made, the estate will most likely fulfil the contract since the estate usually prefers to get the full price in exchange. ${ }^{3}$ In cases where the delivery has not been made but the buyer has already paid (all or part of the price), the bankruptcy estate may refuse to deliver the item, and rather re-sell it. In this situation, it is possible for the original buyer to re-purchase the item, but she would have to pay once again. This is because the bankruptcy estate does not have to repay the prepayment since the recovery claim for the prepayment is treated as any other credit claim. Since the buyer is not among the prioritised creditors, she (or he) will, at most, receive a dividend of her (first) payment.

This study is framing the problem described above as a problem of competing claims for priority. The main question raised in this study queries whether policymakers should favour the principle that prioritises buyers with valid contracts for the undelivered items or the principle that treats such buyers as equal to other unsecured

\footnotetext{
1 Different legal systems, due to different legal traditions, employ different ways to implement such priority rules. For example, the Swedish rule (section 49 of the Consumer Sales Act, which is limited to consumer sales) only deals with the issue of protecting the buyer against the seller's creditors, whereas in French law (Article 1583 Code Civil), this issue is combined with others and phrased in the Code in terms of the buyer acquiring 'ownership' of the item.

2 Such a rule applies, e.g. in German law (Section 929 of BGB). The same principle applies in US law (section 2-401(2) of UCC), unless otherwise agreed that the 'title' passes when the goods are delivered. Note that there are more rules relevant in giving a thorough description of the US situation, e.g. section 541 of the US Bankruptcy Code. According to the section, all legal and equitable interests of the debtor in a piece of property, as of the commencement of the case, will form part of the debtor's estate. However, note also that generally, bankruptcy courts will consider property rights determined under the state law (such as individual state legislation incorporating the UCC) to decide which assets form part of the debtor's estate in bankruptcy.

${ }^{3}$ Unless the market price of the specific object has increased more than the costs of another sales transaction have increased.
} 
creditors. These two principles have been adopted differently in various jurisdictions; see Sect. 2, and lawyers and policymakers require that the answer to the question of which principle should be favoured be based on economic reasons. ${ }^{4}$

An advanced purchase (a forward transaction), where the price at which the product will be sold is an outcome of a bargaining process between the buyer and the seller, requires prior agreement between these parties. Such transactions are common among solvent businesses. However, if a company becomes insolvent after such a contract is made but before the product is delivered, bankruptcy laws take effect and claims to the undelivered product become an issue. Our model focuses on the ex ante decision-making behaviour of creditors, buyers, and investors in such an occurrence. We adhere to the creditor's bargaining theory (Jackson 1982; Baird and Jackson 1984; Baird 2017; Casey 2019) and demonstrate how a fictive change in an ex post legal principle will be priced and affect the ex ante bargaining of the different actors with competing claims (Bebchcuk and Fried 1996). We consider that the actors with stronger claims under the bankruptcy will be charged ex-ante fees by other claimholders. There are numerous empirical observations of such 'adjusting' creditors. For instance, a new priority law was introduced in Finland in 1993, through which, secured creditors who, before the law changed had a floating charge that gave them $100 \%$ priority on their collateral, now enjoyed partial priority. The reduced secured creditor's priority was not found to lead to an increase in the postbankruptcy value to be distributed among the creditors; neither did it reduce the cost of bankruptcy [Bergström et al. (2004), compare with Cerqueiro et al. (2016), for the later Swedish example.] Another example is the study by Kale and Shahrur (2007), which shows a significant negative relationship between a firm's debt level and its relationship-specific investments by customers and suppliers. A low debt level acts as a commitment mechanism that induces suppliers and customers to adjust and undertake relationship investments. Similarly, studying the auctions of used cars, Hortacsu et al. (2013) find that customers discounted the price of the cars sold by distressed firms and the future expected loss of valued 'amenities' reduced the consumer's willingness to pay. These examples show that it is not only professional creditors like banks that adjust to how insolvent company assets will be distributed; even so-called non-adjusting, or involuntary creditors (Baird and Jackson 1984; Bebchcuk and Fried 1996), change their a priori valuations.

We differ from the vast economic literature on value distribution and bankruptcy in that they mainly focus on how well different bankruptcy systems facilitate the transfer of assets to their most productive uses (e.g. Hotchkiss 1995; Maksimovics

\footnotetext{
${ }^{4}$ Recently, this issue has been raised in law reform debates, e.g. in Sweden, the Czech Republic, and Hungary. See the two Swedish Law Commission Proposals SOU 1995:11 (proposing a change from traditio to contract for consumer sales, which was ultimately adopted) and SOU 2015:19 (proposing a change from traditio to contract in general). Regarding the Czech draft proposal from 2005 (also proposing a change from traditio to contract, which was ultimately accepted in the new Czech Civil Code and enforced on 1 January 2014), see Faber (2008, p. 40; $58 \mathrm{ff}$ ). In Hungary, the traditio principle was ultimately kept within the new Civil Code, which entered into force on 15 March 2014, but the concept had been under debate during the drafting stage; see Note 18 to Article VIII.-2:101 DCFR in Lurger and Faber (2011).
} 
and Phillips 1998; Hotchkiss et al. 2007; Bernstein et al. 2018). These empirical economic studies that compare different legal regimes tend to be limited to comparisons between US Chapter 11 and Chapter 7 experiences. For example, Pulvino (1998) shows that the financial conditions of an airline determine the price the airline receives when selling aircrafts, and this reflects the risk that, during bankruptcy procedures, the airline's assets may end up at low-value buyers (e.g. Schleifer and Vishny 1992). Similar to the literature on adjusting creditors, Pulvino suggests that his results may have effects on financial leverage and the cost of capital. In a later study, Pulvino (1999) finds that transaction prices are the same in Chapter 11 and Chapter 7 bankruptcies. A related measurement issue that arises from this relates to how the costs of financial distress are measured. Following Altman (1984, 1993), the practice is to measure financial distress as the difference between the pre-distress market value of a firm minus its post-bankruptcy value minus the gross value recovered by the claimholder (see also Franks and Torous 1994; Branch 2002; Bris et al. 2006). Here, we highlight the importance of interpreting the performance of a legal system correctly (see Sect. 2.3). For instance, if one looks at the advance prices paid in the two systems and finds that the contract regime prices for the advance purchases are higher than those in the traditio regime, it would be erroneous to conclude that the contract regime is economically more profitable to the seller using a proper measure. We show that the higher advance price in the contract regime is compensated for by the reduced pre-bankruptcy risk and, hence, a reduced cost of credit. Looking at only one or the other would be misleading. The more relevant matter is how the priority regime (contract or traditio) affects the decision to invest, the generation of total economic surplus, and its distribution.

When it comes to earlier legal research on which principle should be favoured, we refer to Sect. 2 of this paper. Within the issue of legal systematics, there are legal studies on which principle is the better choice. In the joint research project for the Draft Common Frame of Reference (DCFR, edited by von Bar and Clive 2010), the Study Group on a European Civil Code had such an ambition ${ }^{5}$ and chose the traditio regime. ${ }^{6}$ Interestingly, part of their method was to vote among some of the researchers. ${ }^{7}$ This is not entirely remarkable since the issue was also about a central feature of the entire system of the regulation. Some lawyers consider the systematic aspect of the issue to be the most important aspect. ${ }^{8}$ In another legal and economic study concerning a jurisdiction that uses the traditio principle, it was found that the

\footnotetext{
5 See von Bar and Clive (2010, pp. 4383-4408) and the reactions in European private law doctrine by, e.g. Sagaert and del Corral (2012, p. 343; 349 ff), Håstad (2009, p. 725; 734 ff), Stadler (2010, p. 380; 383 ff), and Walczak (2017, pp. 89-124). Note that the project presented by the editors, von Bar and Clive, was a joint research project and that three of the authors participated in that research project: Faber, co-leader of the sub-working group responsible for developing the rules on the transfer of ownership together with Brigitta Lurger, Martinson, a national reporter on Transfer of Ownership for Sweden, and Andreasson, a co-worker to Martinson.

6 See Article VIII.-2:101 DCFR and the discussion provided by von Bar and Clive (2010, p. 4383).

7 See von Bar and Clive (2010, p. 4383). An extensive account of the Study Group's working method is provided by McGuire (2006, p. 163).

8 See Stagl (2015, p. 9).
} 
economic efficiency of traditio could be questioned, although the researcher found no suitable way to empirically measure the effects (Henriksson 2009, compare Henriksson 2015). For the same jurisdiction, numerous legal studies on which principle is superior also exist. ${ }^{9}$

Our results show that if the priority regimes are known a priori, then the market will price each regime differently and in a way that makes the players indifferent about the regimes. Thus, even though the price of credits may differ between the two regimes, the ex-ante expected surplus would be the same. The pricing differences that occur balance the additional surplus that one gets from a favourable post-bankruptcy priority regime, by reducing the surplus that would have been obtained had a bankruptcy not occurred.

The reminder of this paper is structured as follows. Section 2 explains the legal context and intrigue of the problem under study from a lawyer's perspective. Section 3 develops the study's basic economic model and the resolution thereof for each of the two priority regimes. Section 4 discusses the economic implications of each regime for variables like interest rate and the advance price, and Sect. 5 concludes the study.

\section{Legal context and lawyers' treatment of the problem}

The research question in this article is limited to the choice of principle for buyer priority. It should be noted that, in spite of economic efficiency being a major concern and a cause for argumentation, the perspective adopted for this question is not in all aspects the common perspective among lawyers. There are many available legal studies that would help us explore the legal framework of the question, especially when examining various jurisprudences concerning specific jurisdictions. ${ }^{10}$ However, taking this route would deviate the study from its primary objective, leading it to several research questions related to some of the difficulties of conducting a comparative legal study. Our intention is not to deal with those research questions. ${ }^{11}$ We do, however, need to explain the legal context of this problem in general terms

\footnotetext{
${ }^{9}$ For Swedish law see Myrdal (2002) and Mellqvist (2010). For German law, see Süß (1952). For the analysis of the choice between the traditio and the contract principle from a comparative perspective, see van Vliet (2000). For the same analysis on German, French, English and Dutch law, see Sagaert (2008), Sacco (2009), and Wood (2006). For the development of the principles, see Göransson (1985), Wiegand (2000), and Bucher (1998).

${ }^{10}$ Much of the general understanding on how priority rules are employed within different legal jurisdiction and the motivations thereof can be found in the Draft Common Frame of Reference (DCFR), edited by von Bar and Clive (2010, pp. 4377-4459), in which principles, definitions and model rules of European private law is described, where the relevant provisions in the European jurisdictions are described and a general discussion based on these national foundations is provided. See also the broader descriptions in the series National Reports on the Transfer of Movables in Europe, Faber and Lurger (2008-2011). See also, with a comparative perspective, van Erp and Akkermans (2012, pp. 783-844), von $\operatorname{Bar}(2019$, p. $288 \mathrm{ff})$.

11 We do however intend to do a presentation on what we have found about some of them, see forthcoming.
} 
and discuss the manner in which lawyers treat the issue of competing claims for priority over an insolvent seller's assets. To make these explanations comprehensible, we start by pointing out the functions of the two principles in a way that reflects the legal analysis behind our perspective.

\subsection{Functions of the principles in the context of nearby regulation}

The principles of traditio and contract form the first set of rules that lawyers use to determine whether buyers should be given priority in a business' insolvency. The second set of rules at lawyers' disposal in such matters includes those concerning the invalidity of simulated contracts. In all jurisdictions, there are rules providing for the invalidity of contracts and for pretended and fraudulently constructed transactions to be disregarded. For example, when a debtor, together with someone claimed to be the 'buyer', fraudulently purports that an asset was 'sold' prior to the insolvency proceedings, such a 'transaction' is, in one way or the other, ineffective against the other creditors. ${ }^{12}$ There needs to be a true transaction to get priority before the creditors. The third set of rules regulates the possibilities for the recovery of transactions that were not made on market terms. The 'sale' of a piece of property at a low price to the seller's close associates or to others that the seller wishes to favour over other creditors, can be reversed or adjusted based on these rules. The Roman law institute, Actio Pauliana, has influenced our later legal systems. ${ }^{13}$

The functions of the above-mentioned sets of rules in deciding the priority of each party are different. In principle, they address different aspects, although they also partly overlap. Looking at the fundamental functions, the rules on the contractual invalidity of simulated contracts can be used when the legitimacy of a transaction is questionable. The rules of transaction recovery address transactions that are real but not made on market terms. In comparison, traditio and contract principles fundamentally address valid transactions made according to market terms, but create inequality amongst the collective of creditors in that the buyer is seen as one of them, since it is mainly the buyers - who have made advance payments-who are affected by these principles.

It should be noted that both traditio and contract principles serve the function of creating equality among creditors. The difference between the two principles concerns the point in time when priority is granted. With the traditio principle, priority is granted at delivery. In contrast, with the contract principle, priority is granted at the point when the sold asset is specified for the buyer, which may occur at an earlier

\footnotetext{
12 There is a broad consensus among European legal systems that no transfer of property can take place and no priority over the seller's creditors can be obtained in the case of a sham transaction (see the comments and national notes to Article II.-9:201 DCFR, in von Bar and Clive 2010, pp. 611-615.) See also a more recent account by Dedek (2018, pp. 814-819).

13 For references regarding the Actio Pauliana and similar concepts in the various European legal systems, see the national reports published in McBryde et al. (2003) in the respective chapters on 'Reversal of juridical acts (Actio Pauliana)'. See also the principles stated in $\S 8.1$ and $\S 8.2$ (pp. $630 \mathrm{f}$ ) and the related general commentary on $\S 8$ (pp. $53 \mathrm{ff}$ ) in the same volume. Furthermore, see the individual national reports in the series edited by Faber and Lurger (2008-2011).
} 
point than the delivery, and in case of sale of a specific asset is already at the agreement on the contract. Therefore, in practice, the choice between contract and traditio is not a choice of whether the regulation of priority should have an additional rule, in addition to simulation and recovery rules, but an inevitable choice of when the buyer should reach priority.

In addition to the above-described function, it is relevant to note that the traditio principle but not the contract principle, overlaps the functions of the rules of simulation and recovery. If a transaction does not fulfil the traditio requirement, it is not necessary to deal with the evidence on the grounds of simulation or recovery. In some of the debates and legal analyses around the world, this function is seen as the primary function of traditio, while the issue of equality is not even part of the picture. ${ }^{14}$ Another indirect function of the traditio requirement is based on the assumption that the risk for debtors (sellers) becoming over-indebted is less if their buyers have an incentive to not leave the goods with the seller. This is because it is assumed that leaving the goods with the seller gives the seller a chance to use the goods to get liquidity through another sale or as security for credit. ${ }^{15}$ In addition, there are differences in the sanctions that make traditio preferable for the creditors, as compared to recovery.

\subsection{Relevance and irrelevance of ownership and transfer of ownership}

One reason behind many lawyers having differing perspectives, both amongst themselves and from ours in this study, is that they make a connection between when a buyer obtains priority against the seller's creditors and the systemic structure of the property law regulations in their jurisdictions. ${ }^{16}$ Thus, the question of priority for buyers, in several cases, becomes a question of the transfer of ownership. ${ }^{17}$ This is a

\footnotetext{
${ }^{14}$ This is a possible effect of approaching the issue as a matter of ownership and transfer of ownership even though the ambition is a functional one, like in Sagaert (2008) or Swedish Supreme Court decision NJA (2008) p. 684 Sannäs räkor.

${ }^{15}$ See, for instance, the discussion provided by Martinson (2002, p. 311). As a general point, note that the functions of the rules are dependent on how they are used and the other possibilities that the regulation in a particular jurisdiction brings. The functions we have described in this section come from the perspective we adopted in our analysis of the regulation of buyer priority. For functions used in legal research, see von Bar and Clive (2010, pp. 4383-4408), Henriksson (2009, pp. 161-177, 213-253), Faber et al. (2012, p. 10; p. 19 ff, 38 ff), and Faber and Lilja (2012, p. 232) who discuss particular examples.

${ }^{16}$ For a comprehensible perspective to the profound weight that lawyers put on the systemic aspects of the question, see Sagaert (2008), who uses the description of a 'holy war of the classical dogmas'.

${ }^{17}$ Rules on the transfer of ownership (or title), which also govern the matter of a buyer's priority over the seller's creditors as discussed in the present article, apply, for example, in German (Sections $929 \mathrm{ff}$ of the BGB), English (Sections 17 of Sale of Goods Act 1979), Dutch (Section 3:84 BW), French (Section $1138 \mathrm{Cc}$ ), Spanish (Section $609 \mathrm{Cc}$ and other provisions), and Austrian law (Sections $423 \mathrm{ff}$ ABGB). For a detailed account, see the national reports for all European legal systems except the Nordic countries in the series Faber and Lurger (2008-2011). The US law deliberately seeks to take a different starting point by not making particular matters depend on the passing of the 'title', but contains a residual rule for matters not regulated in a specific manner. According to this provision (Section 2-401(2) of UCC), unless otherwise agreed, the 'title' passes when the goods are delivered. Note that there are some specific provisions in the UCC dealing with the conflict between the buyer and the seller's creditors (such as
} 
question connected to several other possible conflicts concerning competing claims and the circumstances around contractual agreements, delivery, etc. von Bar and Clive (2010) writes,

In most European countries there are rules defining the right of ownership ... and rules defining a particular moment when this right of ownership passes from the transferor (owner) to the transferee. At this moment all 'aspects' related to the right of ownership as defined, like the owner's right to recover possession of the property from another person even if that other person is insolvent (i.e. protection as against that other person's general creditors). (pp. 4379-4380)

The idea of a unitary starting point for how to resolve all these conflicts affects the perspective, both consciously and subconsciously. ${ }^{18}$ Even in jurisdictions that do not use a system that considers the transfer of ownership as the starting point, the lawyers' thinking has been affected by notions of ownership. ${ }^{19}$ Through different jurisdictions, it is possible to find variations of the argument that buyers who do not get what they bought are treated unfairly. ${ }^{20}$ As such, the issue is put in terms of the buyers' possibilities to obtain 'protection' against the other creditors. ${ }^{21}$ Arguments

\section{Footnote 17 (continued)}

Section 2-502 of UCC). However, it turns out to be highly problematic regarding whether these provisions actually provide protection to the buyer in the seller's bankruptcy (i.e. in the situation where this protection would be needed most). Rather, Section 541 of the US Bankruptcy Code, according to which all legal and equitable interests of the debtor in property as of the commencement of the bankruptcy proceedings will form part of the debtor's estate, apparently operates to the effect that the (residual) rule on the passing of the 'title' in Section 2-401(2) of UCC becomes material for the buyer's priority in bankruptcy. See the discussion and references provided by Lilja (2014, p. 52, pp. 85 ff).

18 This has at least been a major concern in some parts of legal discussion for a long time. See Llewellyn (1938, 15 N.Y.U. L.Q. Rev. 159, p. 169), Alf Ross (1956-1957, p. 70), and Brækhus (1988, p. 6). For a recent example moving beyond property law, see Faber and Martinson (2019, p. 85-123).

19 The concept of a unitary 'transfer of ownership' is not used in, for example, the Nordic countries, see the national reports for Sweden, Norway, Denmark and Finland in Lurger and Faber (2011, volume 5), von Bar and Clive (2010, p. 4380), and Martinson (2006). Nevertheless, it is quite common for Nordic lawyers to speak of 'ownership' in order to describe certain aspects of a person's legal position. See, for instance, Hessler (1973, p. 42 ff). Occasionally, the terms 'owner' and 'ownership' are used in legislation, such as in Sections 2-8 of the Swedish Act on Good Faith Acquisition (SFS 1986:796). In addition, the notion of 'ownership' appears in contract documents such as insurance policies and must, therefore, be dealt with by the courts, which sometimes causes difficulties in legal reasoning. An illustration for the latter aspect can be found in the Swedish Supreme Court Case NJA 2010 s. 227.

${ }^{20}$ The argument that it would be unfair for an honest buyer to lose both the value of the payment and the goods while the creditors receive both the payment and the goods (so that they earn a 'double profit') is critically discussed, for instance, by Göransson (1985, p. 446), von Bar and Clive (2010, p. 4398 f).

${ }^{21}$ It has become common, particularly in Sweden, to address the issue of a buyer's priority over the seller's insolvency creditors as the 'protection' of the buyer against the creditors (or short: 'protection against creditors'). See, for instance, Hessler (1973, fn. 14; p. 90 ff) and Håstad (1996, p. 93 ff, 205 ff). Via the Study Group's work, to which Håstad was an influential member, describing the particular legal problem as one of the 'transferee's protection against the transferor's creditors', see von Bar and Clive (2010, pp. 4388-4390). The description became somewhat common in the European private law discourse. The potentially deceptive function of emotive language used in the present context is analysed by Faber and Lilja (2012, 232 fn. 10, p. 272 f). 
for taking this perspective suggest that it is 'natural' and even 'fair' that a buyer receives the item they purchased. ${ }^{22}$ The politically idea that 'ownership' is a 'right' that must be respected is, in this way, used in what can be seen as out of context. von Bar and Clive (2010) state that,

Consensual model coincides with "natural expectations" of the parties, etc. It is sometimes stated that ordinary people-or ordinary business people-consider it "natural" that a buyer (or other transferee) acquires a right to separate the (specific) goods upon concluding the contract for sale. (p. 4389)

Unsurprisingly, these arguments for ownership, rights, and fairness can be easily reversed. Lawyers who favour the traditio principle argue that a prepaying buyer is not significantly different from other creditors who have given the debtor credit. Therefore, it is 'fair' that the buyer should not be treated better than other creditors in accordance with the principle of equal payment. von Bar and Clive (2010) describe this view, stating that,

[A] transferee of specific goods is a general creditor like others. Unless ownership has already passed under a contractual agreement for an immediate transfer or a rule of law to this effect, a transferee of specific goods who has concluded a contract for sale but has not yet taken delivery and against whom, therefore, the transferor is simply obliged to transfer the ownership, is nothing but a general creditor of the transferor. (p. 4396)

We will make some comments on these themes in the following sections, which is important also on a terminological level. In this section, we only elaborate our research question. We have chosen this question on buyer priority since priority is the relevant economic function of the choice between traditio and contract. Therefore, the focus of this study is the issue of priority. In this context, ownership is just a linking concept and the transfer of ownership is a superstructure ${ }^{23}$; here, these two are not the real issue. ${ }^{24}$ In sum, we have singled out one issue: the preferred choice of principle in determining the prioritisation of buyers over an insolvent seller's other creditors. ${ }^{25}$

\footnotetext{
22 See, for example, von Bar and Clive (2010, p. 4385, 4389), SOU 1995:11 (p. 217), and SOU 2015:18 (pp. 89-90, 102). Additionally, compare the introductory example of Göransson (1985, p. 19). Not surprisingly, arguments of this kind can be, and are, put forward for various solutions. Some German authors of the Pandectist movement of the late nineteenth century, building on ancient Roman authorities (Institutiones Iustiniani, 2, 1, 41), claimed that it would be 'natural law' that a buyer acquired ownership (and hence gained priority over the seller's creditors) upon paying the price. See Windscheid and Kipp (1906, 892 fn. 19a) with further references. This idea has been re-introduced to the contemporary discourse by Stagl (2015, p. 1, 28 f).

23 We do not claim that a so-called unitary approach is in any way less valuable than a functional issueby-issue approach. See von Bar and Clive (2010, pp. 4379-4380).

24 The idea of a 'real' issue might seem provocative, but the expression is not intended to provoke. It is in line with Scandinavian legal thinking, see, for example, Faber and Martinson (2019, pp. 85-123) with references.

${ }^{25}$ Compare the issue-by-issue approach of the Study Group on a European Civil Code, as described by Faber (2010, p. 502). See also von Bar and Clive (2010, pp. 4377-4459) and von Bar (2019, p. 357 ff). Applying a 'narrow issue approach' in the law of sale of goods has also become a paramount draft-
} 
The fact that we have singled out one issue does not mean that we see the systemic aspects as irrelevant. On the contrary, the relevance of these aspects is acknowledged, particular given that different solutions form a system of solutions in different jurisdictions. In view of such systems and their overall effects, it is therefore possible that the contract principle is a more effective solution in one jurisdiction, while traditio is more effective in another. What we investigate, however, is whether policymakers should favour one principle over another with regard to priority for buyers. Note that it is the policymakers we are investigating, and that this can be a legislator or body in a position to decide the common terms of a specific market. In most jurisdictions with a traditio principle, it is possible to use standard contracts that depart from the traditio requirement and instead use the requirement of specificity used under the contract principle. It is even possible for two parties to individually depart from traditio when it suits the situation. ${ }^{26}$

\subsection{Dissent among lawyers' perspectives on priority—lawyers created reality}

The disagreement between lawyers on this matter does not imply their disinterest in the economic effects of the regulation. On the contrary, economic efficiency has been a major concern and an evident cause for argumentation. In their debates, lawyers have made different assumptions to promote one principle over the other, as well as advocated for how strictly the respective principles should be used. Such argumentation and the assumptions behind it can be found in several kinds of legal contexts, including in research, the reasoning of Supreme Court Judges, and proposals to change regulation. ${ }^{27}$

Those who prefer traditio claim that this principle is necessary to discourage fraud. Such fraud is the result of asymmetric information where the manager of a company learns of the possibilities of a bankruptcy before the other stakeholders, such as the company's creditors. In such a case, the debtors may try to transfer value from the company to their friends and preferred business relations before going bankrupt by committing to under-priced deliveries. In particular, these lawyers

\footnotetext{
Footnote 25 (continued)

ing objective for Article 2 UCC. See the main draftsman, Llewellyn (1938, p. 159, 163) and the Official Comments to Sections 2-101 and 2-401 UCC ('step by step performance'). For some context, see Twining (2012, p. 136 f).

${ }^{26}$ It is in many jurisdictions, with the exemption of the Swedish, possible for the seller and buyer to contractually determine the point in time that the buyer gains priority over the seller's creditors (most often phrased in terms of transferring 'ownership'). This is most directly spelled out in Section 17 of the English Sale of Goods Act, 1979, and Section VIII:-2:101 DCFR, but accepted in other systems as well. See the conclusions drawn by van Vliet (2000, p. 201 f). There is even support that, historically, the "contract principle' emerged from commercial practices when parties used to contract for a kind of fictitious traditio in the late eighteenth century France; see Sagaert (2008, p. $11 \mathrm{ff})$.

27 SOU 2015:18 (pp. 99-102). Swedish Supreme Court decision NJA (2008, p. 684 Sannäs räkor), especially in, p. 684), especially in Justice Håstad's reasoning (arguing that the only value of the tradition principle would be that the efficiency of enforcement proceedings are improved considerably because predated and false assertions upon enforcement are neutralised). See also the deliberations reflected in von Bar and Clive (2010, p. 4391 f).
} 
contend that the contract principle may be used by a debtor claiming that specific assets have already been sold when creditors arrive in the event of a bankruptcy. The traditio principle is assumed to lessen the level of this risk since the goods must be moved to the buyer in order to be safe from the seller's creditors. This assumption is often retold among lawyers but seldom backed up, apart from using anecdotal experiences. The empirical evidence for this argument is scarce, but there is an odd example from the Netherlands dating back to 1936. That empirical study showed that in most districts of the Netherlands at that time, 50-90\% of all judicial executions over corporeal movable assets proved unsuccessful because of prior transfers of ownership for security purposes, of which $90 \%$ were assumed to be simulated (Meijers 1936). ${ }^{28}$

Among those who favour the contract principle, the assumptions may trigger concerns about international competition. Suppose a buyer could carry out an advance purchase (pay now for delivery later) from company $A$ operating in a jurisdiction that follows the traditio principle, or from company $B$ in a jurisdiction that follows the contract principle. If both companies have equal chances of going bankrupt, the consumer will prefer to buy from company $B$ as it provides a greater assurance of delivery. This will make it more difficult for company $A$ to attract advance purchases and, if this is an integral part of their business, reduces the ability of company $A$ to compete with company $B$ for buyers who can operate in either jurisdictions. Assumptions like this have been used as decisive arguments in the legislation process, such as in the Swedish law commission proposal SOU 2015:18, where a proposal was made that the Swedish traditio principle should be replaced with a contract principle. The assumption of the Swedish Inquiry is one that is not supported by an actual study. These assumptions are conveyed in SOU 2015:18, stating that,

In many comparable countries, the law of property is based on a contractual principle of some kind ... For international manufacturing purchases, agreements regularly prescribe that manufactured products become the buyer's property as soon as they are individualised. When a Swedish company sells according to these conditions, the traditio requirement means that the condition of ownership becomes ineffective. In such a situation, the buyer may require more extensive financial guarantees or ultimately chooses a seller from another country than Sweden, (p. 92).

Among jurists' conceptions, there are direct inaccuracies as well. One example is the claim that the traditio requirement results in transaction costs for all transactions. $^{29}$ Thus, lawyers have failed to exclude, in transaction cost terms, those transactions where the parties, for reasons other than the traditio requirement, carry out

\footnotetext{
28 The study by Meijers (1936) was followed by a change in the Dutch Civil Code. It requires delivery for a transfer of ownership (which implies that only from the point of delivery will the buyer get priority before the seller's creditors), and goes even further by providing that fiduciary agreements including transfers for security purposes cannot form a basis for a valid transfer; see Section 3:84 paragraphs (1) and (3) Dutch Civil Code.

29 As in the Swedish law commission proposal (SOU 2015:18 p. 90-92, 96), see the analysis in Andreasson et al. (2015 p. 709, especially 712-716).
} 
delivery at the time of purchase anyway. In the same way, lawyers have failed to consider that it is probably mainly prepaying buyers who incur losses because of the traditio requirement. ${ }^{30}$ Lawyers have claimed that all buyers are affected by the traditio requirement, even though a bankruptcy trustee has significant reason (such as transaction costs) to want to fulfil an agreed sale at market price.

Lawyers from jurisdictions with fairly similar societies use different conceptions of economic conditions to justify the principle they use themselves. For example, the traditio principle can, in one jurisdiction, be motivated primarily by the risk of pretended and fraudulent transactions, while the argument that property in the debtor's possession gives the appearance of false wealth is considered outdated. At the same time, it is possible to find that other jurisdictions consider such false wealth viable, while the risk of pretended and fraudulent transactions is seen as small and is scarcely mentioned. ${ }^{31}$

Although there are numerous other examples that could be mentioned regarding how lawyers justify their perspectives, these are not the focus of this article; but rather, this subsection simply explains part of the reason our research question is relevant. However, it is worth noting that the variations in lawyers' assumptions seem to follow legal traditions rather than differences in the economic conditions of our societies. This makes an interesting study in itself, and one aspect that can be examined here is the economic assumptions that lawyers in a specific legal tradition make. This constitutes a special phenomenon that has been aptly called the lawyercreated reality. ${ }^{32}$ However, this theme is beyond the scope of this study. ${ }^{33}$

\subsection{Overview of the differences in the choices of principle}

To further illustrate why the choice of principle is an interesting issue, we present an overview of the principles different jurisdictions use. It is important to note that there are dissimilarities between the different traditio principles and contract principles. For example, a contract principle may give precedence to one party based on the conclusion of the agreement or the fact that the buyer or seller, in addition to entering into a contract, also acted in a certain manner. ${ }^{34}$ Similarly, the traditio principle has variations. For example, this principle can impose an absolute requirement that can only be replaced by a registration measure; but it can also be dispositive so that buyers and sellers can agree on the seller holding the purchased item on

\footnotetext{
30 Again, as in SOU 2015:18 (p. 62) and the analysis in Andreasson et al. (2015 p. 709, especially 712716).

31 This is a research question on its own, but compare, for example, the rather different conceptions of the two law commissions of England and Sweden. The Law Commission Consultation Paper No $164 \mathrm{p}$. 1-3, and SOU 2015:18 (p. 124).

32 Graver (1986).

33 We intend to return to this theme in another context.

34 For example, Section 18 of the English Sale of Goods Act of 1979 provides a number of rules concerning specific situations which take precedence over the general fallback provision that property passes (and hence the buyer assumes priority over the seller's creditors) upon the conclusion of the contract.
} 
behalf of the buyer after the purchase. ${ }^{35}$ This kind of agreement can be instituted under various terms and may describe the point in time at which the buyer should be prioritised over the seller's other creditors. ${ }^{36}$ Regimes that allow this diversion from traditio may lead to difficulties in interpreting what the parties have agreed upon, and depending on how these aspects are treated in the regime, it may be questionable whether such a regime should be seen as a traditio or contract regime. ${ }^{37}$ Table 1 gives the basic principles followed by different countries. Since there are many variations and nuances in the different regimes, the table should be regarded as a rough simplification, indicating whether a legal system for a sale of goods applies a contract principle or requires delivery, i.e. traditio.

If we assume that the above list gives us reliable information and a rough picture of how various jurisdictions apply the principles, we can draw the conclusion that there is no clear overweight for any of the two principles. ${ }^{38} \mathrm{We}$ can also conclude that neighbouring countries with similar circumstances have chosen different regimes.

Since our ambition is to show a general difference between contract and traditio, we begin with simplifications; that is, we consider the contract principle to require a contract and that the object be specified, and regard the traditio principle as requiring an agreement and a delivery, i.e. that the buyer has taken possession of the purchased item.

\footnotetext{
35 Germany and Austria represent the second, very common, regime, where statutory law provides for different 'forms' of traditio, including one which makes it possible to transfer the goods before delivery (the so-called constitutum possessorium, see Section 930 of BGB and Section 428 of ABGB), which can be analysed in terms of a 'dispositive' traditio system. See, among many others, van Vliet (2000, fn. 21 , p. $201 \mathrm{f}$ ). Sweden represents the first regime with an absolute requirement for delivery or registration, see SOU 2015:18.

${ }^{36}$ This is, although phrased in terms of a transfer of 'ownership', quite directly spelled out in the DCFR rules VIII.-2:101(1)(e) and VIII.-2:103; see von Bar and Clive (2010, pp. 4381-4408, 4475-4478).

37 The regimes in Spain and Norway are two different examples of this kind of classification difficulty. See von Bar and Clive (2010, pp. 4484-4485, 4489).

38 This overview is based on information from the national reports edited by Faber and Lurger (20082011) and von Bar and Clive (2010 pp. 4479-4490), SOU 2015:18 (pp. 73-87). For countries not covered by these sources, see the following: For Japan, Zufall (2010, p. 201), which refers to Section 178 of the Japanese Civil Code for the opposability of a transfer in the transferor's insolvency. For India, Section 20 of the Indian Sale of Goods Act 1930 (as the relevant fallback rule for a sale of specific goods in a deliverable state). For Quebec, Section 916 of the Civil Code of Quebec, for the other Canadian provinces see the respective Sale of Goods Act (following the English Sale of Goods Act). For China, Section 23 of the Chinese Property Law Act, and Lohsse and Jin (2015, 227 nos. 63 ff). For Turkey, Section 890 of the Turkish Civil Code, and Rumpf (2004, p. 245). For South Korean law, Section 188 South Korean Civil Code. For Russia, Section 223 Russian Civil Code. The basic traditio rule in Brasil is spelled out in Section 1267 of the Brasil Civil Code; for more details (including a special provision requiring registration for third-party effectiveness regarding automobiles), see Pietrek (2015, $84 \mathrm{ff}$ ). For the Philippines, see Section 1164 of the Philippine Civil Code, and Delson (2000, p. 185 f).
} 
Table 1 Regimes followed by different countries
Countries following the contract regime

Countries following the traditio regime

\begin{tabular}{ll}
\hline France & Germany \\
Belgium & Switzerland \\
Italy & Austria \\
& Slovenia \\
Portugal & Spain \\
Luxembourg & Netherlands \\
England & \\
Scotland & \\
Ireland & \\
Iceland & \\
Denmark & \\
Sweden (consumer) & \\
Finland & Norway \\
Poland & Sweden (non-consumer) \\
Bulgaria & Estonia \\
& Latvia \\
& Lithuania \\
Malta & Hungary \\
Cyprus & Czech Republic \\
India & Slovakia \\
Quebec & Greece \\
& Turkey \\
Japan & China \\
& Canada (rest) \\
& United States \\
& Russia \\
South Korea \\
Philippines \\
Brasil \\
\\
\end{tabular}

\section{The model}

\subsection{Developing the model}

There are many reasons for buying things in 'advance'. One such reason is when a seller produces a product specifically for one buyer. Because the product is being customised for that particular buyer (e.g. based on technical specifications that are unique to the prospective buyer), two issues arise. First, it is difficult to anticipate the market price for such a product. Second, it is less costly to initiate the customisation of the product early on in the production process.

Our model starts with an uncertain project that requires an investment of $I>0$ to get started. There are two investors, an equity owner, and a creditor (bank). The 


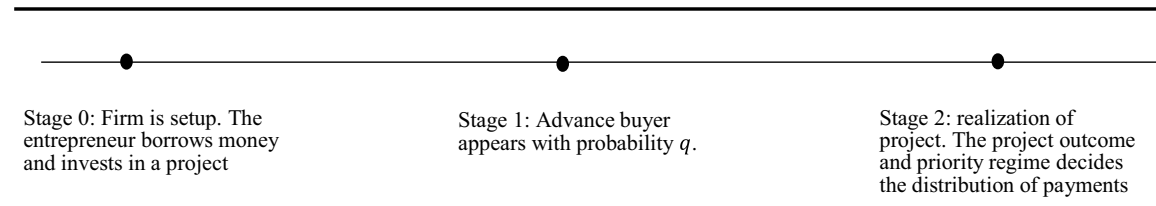

Fig. 1 Timeline

bank invests a loan amount $L$ while the equity owner invests $A \equiv I-L$. We will assume that the risk-free interest rate on the loan is zero and the bank operates in a competitive market. For its loan $L$, the bank has a debt claim of $D$, payable when the project return is realised. In its usual course, the project yields a return $R$ if it is successfully completed and return $r$ if it is unsuccessful, $r$ where $R>r \geq 0$. The project succeeds with probability $p$ and fails with probability $(1-p)$. The uncertainty in the project returns is due to the uncertain market conditions that will prevail in Stage 2. If market conditions are good, the project realises the higher return $R$; otherwise, it returns a value of $r$. The reality of the business's limited liability introduces bankruptcy possibilities, as the bank may not be fully repaid when the project fails. Of course, when the project succeeds there is enough to pay the bank.

Additionally, there is a possibility that after the project commences, and before it concludes, an advance buyer will ask for a product that entails a cost $m>0$, for which the buyer is willing to pay an advance price $v \geq m$, an amount payable before the realisation of the project. This happens with probability $q, 1 \geq q>0$. The possible presence of the advance buyer makes the bankruptcy process slightly complicated if the firm enters bankruptcy before the product is delivered to the buyer. There are now two prior claimants at the end of the project, the bank and the advance buyer. ${ }^{39}$ Thus, this study's question is, 'should the advance price $v$ be returned (or the product be delivered) to the advance buyer even if the bank (lender) is not fully repaid?'

Figure 1 gives the timeline or sequence of events in the model. In Stage 0, the firm is set up with a limited liability debt contract. In Stage 1, an advance buyer may, or may not, appear. In Stage 2, the project realisation happens.

The customised product has a market value $v^{\prime}$ at the end of the project, but is valued at $v^{\prime \prime} \geq v^{\prime}$ by the advance buyer. Since the product is customised to a specific buyer, the latter's valuation is more than what the average (market) buyer is willing to pay for it.

Consider a car company selling cars in two popular colours, both at the cost $v^{\prime}$. Consider also that a customer wants a third colour, which she particularly prefers, but the company does not offer that colour because its cost is higher than what the market is willing to pay. If the car company uses this third colour on some of its cars, it would have to sell all its cars at the same price, despite the ones in the third colour costing the company more to produce. In this example, not only is the customer who wants the rare colour willing to bear the cost of that colour, but she may actually be willing to pay a premium price $\left(v^{\prime \prime}\right)$ for it.

39 The equity owner is a residual claimant and has the last priority. 
Alternatively, consider a company that produces a good that is used as an input in the production of many other goods. The advance buyer in this case may be a producer requiring a unique specification for this intermediate good, given the design of her final product. Since this intermediate product would have little (sold as scrap) or no market value, its market value $v^{\prime}$ would be low, but its value to the advance buyer $\left(v^{\prime \prime}\right)$ would be high. Indeed, this also explains why the supplier of the advance purchase would insist on a commitment by the buyer before producing such a customised product.

Should the project be successful, the market value $v^{\prime}$ would become irrelevant since the lender would be fully repaid. The customised product would go to the advance buyer and not put on the market. However, should the project fail and the bank has the first claim, then, if need be, the bank could put the advance buyer's product on the market and collect a value of $v^{\prime}$. The market condition does not affect the values of $v$ and $m$ as they are determined in Stage 1, before the uncertainty is resolved (in Stage 2).

In such situations, it is important to understand the role played by the advance buyer. Suppose the project involves the production of cars. The advance buyer may want a customised car, where the customisation must happen during the process of production. ${ }^{40}$ This can happen only if the buyer of this customised product makes the commitment to buy it before the completion of the project. This customisation would be an additional cost $m$ in the project, and so the final return would be reduced by $m$. On the other hand, because the product is customised, its value to the advance buyer would be $v^{\prime \prime} \geq v^{\prime}$. Should the project succeed, the value in the project available to the investors would be $R-m+v{ }^{41}$ Should the project fail, the value available in the project to pay the bank would be $r-m+v$ if the product has to be delivered to the advance buyer. If, however, the bank has the first claim on the undelivered product, the amount available to them would be $r-m+v+v^{\prime}$. We assume that at Stage 0 , both the bank and equity owner know that, with probability $q$, an advance buyer may appear in Stage 1 .

Let (superscript) $C$ denote the contract regime, through which the advance buyer has the first claim on the undelivered product during bankruptcy, and (superscript) $T$ denote the traditio regime, through which the bank has the first claim on all the assets (including the undelivered product). Let $D^{j}, j=C, T$ be the debt claim of the bank under priority regime $j$. Under $C$, the advance buyer pays an advance price $v^{C}$ to obtain a surplus of $v^{\prime \prime}-v^{C}$, where $v^{\prime \prime}$ is the advance buyer's valuation of the customised product. As explained before, $v^{\prime \prime} \geq v^{\prime}$ since the product is customised to the advance buyer's preferences and not the general market's preference. If we are in the contract regime, then the advance buyer's surplus, $\Omega^{C}$ is non-stochastic and $\Omega^{C}=v^{\prime \prime}-v^{C}$.

\footnotetext{
40 The customised product could satisfying the specifications of any single buyer. Continuing with the example of the automotive sector, the product could be sheets of steel that will be used for a specific car's chassis, produced by a separate company.

41 The project also has the undelivered product, but it goes to the advance buyer.
} 


\subsection{Solving the model}

\subsubsection{The contract regime}

There are two variables, $v^{j}$ and $D^{j}$, to solve in each regime $j, j=C, T$. Let us consider the contract regime first. The advance buyer is contracting for a product that is customised to her specification for a value $v^{\prime \prime}$ that she gets from the customisation. This customisation comes at a cost $m$, generating a total surplus $v^{\prime \prime}-m$. This surplus will have to be distributed between the project and the advance buyer. The distribution has to be decided through a bargaining process between the advance buyer and the decisionmaker in the project, who, in our case, is the entrepreneur or the equity owner. However, we will not investigate the bargaining process between the two in this study, but merely solve for it. One possible way to solve for the outcome of the bargaining game is to assume that the two parties go through a Nash bargaining process. In that case, the proportion of the surplus going to each party depends on their relative bargaining strength. We will take that as a given and say that $v^{C}$ is the advance price that generates the Nash bargaining solution. Here, the advance buyer receives the surplus $v^{\prime \prime}-v^{C}$ and the project receives $v^{C}-m$.

We will denote the net surplus of the equity owner, bank, and advance buyer in each regime $j$ to be $\Pi^{j}, \Gamma^{j}$, and $\Omega^{j}$, respectively, where $j=C, T$.

Result 1 Let $v^{C}$ be the price paid by the advance buyer, where $v^{C}$ is the outcome of the Nash bargaining process between the advance buyer and the project. Then

$$
\Omega^{C}=v^{\prime \prime}-v^{C}, \Gamma^{C}=0 \text { and } \Pi^{C}=[p R+(1-p) r-I]+q\left(v^{C}-m\right)
$$

(For proof, please see “Appendix”.)

The surplus in the system is distributed among the equity owner, bank, and the advance buyer. The bank is competitive, hence it cannot make a positive surplus. The surplus generated in the project without the advance buyer is $[p R+(1-p) r-I]$ and the equity owner keeps all of it. The presence of the advance buyer generates an additional surplus $v^{\prime \prime}-m$, which is divided between the equity owner and the advance buyer. This division is determined through Nash bargaining, which generates $v^{C}$, giving the equity owner a surplus $v^{C}-m$ and the advance buyer, surplus $v^{\prime \prime}-v^{C}$. However, because the advance buyer appears with probability $q$, the surplus going to the equity owner is probabilistic.

Result 2 Let $v^{C}$ be the price paid by the advance buyer, where $v^{C}$ is the outcome of the Nash bargaining process between the advance buyer and the project. Then

$$
D^{C}= \begin{cases}L & \text { if } L \leq r \\ \frac{L-(1-p)(1-q) r}{p+(1-p) q} & \text { if } r<L \leq r+\left(v^{C}-m\right)[p+(1-p) q] \\ \frac{L-(1-p)(1-q) r-(1-p) q\left(r+v^{C}-m\right)}{p} & \text { if } r+\left(v^{C}-m\right)[p+(1-p) q]<L \leq I\end{cases}
$$


(For proof, please see “Appendix”.)

\subsubsection{Traditio regime}

In the traditio regime, unlike in the contract regime, the advance buyer is not sure of obtaining $v^{\prime \prime}$ at the end of the project, thus her surplus is stochastic. This is because if the project fails, the undelivered product will belong to the bank, where the bank will have to be paid more than $r-m+v^{T}$.

However, before calculating the advance buyer's surplus in the traditio regime, we need to make an additional point. Whenever the bank sells the undelivered product on the market, the advance buyer should be the one buying it. If she does not buy it, the value she receives in Stage 2 is zero, making her net return negative as she had already paid $v^{T}$ in Stage 1 . On the other hand, if she buys it, she will receive a positive value $v^{\prime \prime}-v^{\prime} \geq 0$ in Stage 2 against the price she had already paid. Note that the price $v^{T}$ is a sunk cost in Stage 2.

Under $T$, there are two different situations to consider:

(a) $r-m+v^{T} \geq D^{T}$ : In this case, though the project has failed, the value of $v^{T}$ is sufficiently high so that the bank gets fully paid and the advance buyer receives her full value $v^{\prime \prime}$ (or, a net surplus of $v^{\prime \prime}-v^{T}$ ).

(b) $r-m+v^{T}<D^{T}$ : Here the bank will lay claim to the undelivered product and sell it at $v^{\prime}$. This will increase the value in the project to $r-m+v^{T}+v^{\prime}$. If this is greater than $D^{T}$, the bank will receive $D^{T}$ and the advance buyer will receive the remainder, which is equal to $r-m+v^{T}+v^{\prime}-D^{T} .{ }^{42}$ If, on the other hand, $r-m+v^{T}+v^{\prime}<D^{T}$, there will be no remainder for the advance buyer. To receive her customised product when the company is bankrupt, the advance buyer has to pay $v^{\prime}$ which, as argued before, she does.

Putting these together, the advance buyer pays $\min \left[v^{\prime}, \max \left\{r-m+v^{T}-D^{T}, 0\right\}\right]$ to obtain a Stage 2 value equal to

$$
\left[v^{\prime \prime}-\min \left[v^{\prime}, \max \left\{D^{T}-\left(r-m+v^{T}\right), 0\right\}\right]\right.
$$

If $r-m+v^{T} \geq D^{T}$, then $\max \left\{D^{T}-\left(r-m+v^{T}\right), 0\right\}=0$ and $\min \left\{v^{\prime}, 0\right\}=0$, giving a Stage 2 value equal to $v^{\prime \prime}$. If, on the other hand, $r-m+v^{T}<D^{T}$, the bank lays claim to the undelivered product, which can be bought by the advance buyer with an additional amount that equals the shortfall of $r-m+v^{T}$ from $D^{T}$ but not more than $v^{\prime}$, which is the maximum that can be obtained in the market place for the customised product, the Stage 2 value received by the advance buyer will be less than $v^{\prime \prime}$ but no less than $v^{\prime \prime}-v^{\prime}$. Of course, all of this may only

\footnotetext{
42 Note that if the product, on which the advance buyer has a claim prior to equity, has to be sold in the market, then the surplus generated over $D^{T}$ goes to the advance buyer and not to the equity owner.
} 
happen if the project fails; otherwise, the advance buyer receives the full value $v^{\prime \prime}$ in Stage 2. Thus, we can write the traditio regime surplus of the advance buyer as

$$
\Omega^{T}=p v^{\prime \prime}+(1-p)\left[v^{\prime \prime}-\min \left[v^{\prime}, \max \left\{D^{T}-\left(r-m+v^{T}\right), 0\right\}\right]\right]-v^{T} .
$$

There is no reason for the relative bargaining strength between the entrepreneur and the advance buyer to be different in the two regimes. Hence, compared to the contract regime, in the traditio regime, the bargaining strengths remain the same, but the distribution of the surplus is now dependent on the fact that, should the project fail, the lender/bank is a superior claimant compared to the advance buyer. This implies that the price the advance buyer will pay will be different from that in the contract regime. This follows from equating $\Omega^{C}$ to $\Omega^{T}$ (above). Setting $\Omega^{T}=\Omega^{C}$, gives us

$$
\begin{aligned}
v^{\prime \prime}-v^{C} & =p v^{\prime \prime}+(1-p)\left[v^{\prime \prime}-\min \left[v^{\prime}, \max \left\{D^{T}-\left(r-m+v^{T}\right), 0\right\}\right]-v^{T}\right. \\
& =v^{\prime \prime}-(1-p)\left[\min \left[v^{\prime}, \max \left\{D^{T}-\left(r-m+v^{T}\right), 0\right\}\right]\right]-v^{T}
\end{aligned}
$$

On simplification, this yields

$$
v^{C}=v^{T}+(1-p)\left[\min \left[v^{\prime}, \max \left\{D^{T}-\left(r-m+v^{T}\right), 0\right\}\right]\right]
$$

Two things are immediate. First, $v^{C} \geq v^{T}$. This is because the second expression on the right hand side of Eq. (2), $(1-p)\left[\min \left[v^{\prime}, \max \left\{D^{T}-\left(r-m+v^{T}\right), 0\right\}\right]\right]$ is always greater than or equal to zero. Second, $v^{C}<v^{T}+v^{\prime}$. This is because the maximum value of the right hand side of Eq. (2) is $v^{T}+(1-p) v^{\prime}=v^{T}+v^{\prime}-p v^{\prime}<v^{T}+v^{\prime}$.

Result 3 Let $v^{T}$ be the price paid by the advance buyer, where $v^{T}$ is such that the Nash bargain process between the advance buyer and the project yields the same distribution, as that in the contract regime (with a surplus generated by the presence of the advance buyer). Then

$$
D^{T}= \begin{cases}L & \text { if } L \leq r \\ \frac{L-(1-p)(1-q) r}{p+(1-p) q} & \text { if } r<L \leq r+\left(v^{T}+v^{\prime}-m\right)[p+(1-p) q] \\ \frac{L-(1-p)(1-q) r-(1-p) q\left(r+v^{T}+v^{\prime}-m\right)}{p} & \text { if } r+\left(v^{T}+v^{\prime}-m\right)[p+(1-p) q]<L \leq I\end{cases}
$$

(For proof, please see "Appendix".)

Note that wherever we had $v^{C}$ in Eq. (2), we also had $v^{T}+v^{\prime}$, for that is the amount available to the bank if the project fails and the advance buyer is present. By inspection, the proof is similar to that of Result 2 substituting $v^{T}+v^{\prime}$ for $v^{C}$.

The traditio regime's return to the equity owner can be written as 


$$
\begin{aligned}
\Pi^{T}= & p(1-q)\left[R-D^{T}\right]+p q\left[R-D^{T}+v^{T}-m\right]+(1-p)(1-q) \max \left\{r-D^{T}, 0\right\} \\
& +q(1-p) \max \left\{r+v^{T}-m-D^{T}, 0\right\}-A \\
= & p\left[R-D^{T}\right]+p q\left(v^{T}-m\right)+(1-p)(1-q) \max \left\{r-D^{T}, 0\right\} \\
& +q(1-p) \max \left\{r+v^{T}-m-D^{T}, 0\right\}-(I-L)
\end{aligned}
$$

Result 4 Let $v^{T}$ be the price paid by the advance buyer, where $v^{T}$ is such that the Nash bargain process between the advance buyer and the project yields the same distribution as that in the contract regime (with a surplus generated by the presence of the advance buyer). Then

$$
\Omega^{C}=\Omega^{T}, \Gamma^{T}=\Gamma^{C}=0 \text { and } \Pi^{T}=[p R+(1-p) r-I]+q\left(v^{C}-m\right)=\Pi^{C}
$$

(For proof, please see “Appendix”.)

This result states that under symmetric information, priority rules do not affect equilibrium surplus. First, observe that bank-lending occurs under a competitive market structure in both priority regimes. Therefore, in both cases, the parties do not realise a surplus, but rather, they break even. Second, since the advance buyer decides to buy (with probability $q$ ) after the contract regime has been chosen, her bargaining strength determines how much surplus she receives. The fact that $v^{C}$ and $v^{T}$ are endogenous allows the advance buyer to get an equal part of the surplus in both regimes. Third, the total surplus in the system, given by the project surplus plus that generated by the advance purchase, is independent of the priority regime and equals

$$
[p R+(1-p) r-I]+q\left(v^{\prime \prime}-m\right)
$$

Since the bank receives a zero surplus and the advance buyer receives the same surplus in both regimes, the entrepreneur receives the same surplus in both regimes as well.

\section{Implications}

While the two priority regimes are equivalent in terms of the potential total surplus and its distribution among the agents, the equilibrium values of the variables in the system will vary according to the priority regime applied. In our view, the variables of special interest are $D^{j}$ and $\nu^{j}, j=C, T$.

From our economic analysis, we know the bank's default risk (as measured by the amount it can extract under bankruptcy) is lower in the contract regime than in the traditio regime. This happens in two ways. First, because $v^{\prime \prime}+v^{\prime}>v^{C}$, the 
possibility of a default is lower in the traditio than in the contract regime. ${ }^{43} \mathrm{Sec}-$ ond, when the loan amount is such that a default could occur in both regimes, the recovery by the bank would be higher in traditio than in contract (again because $v^{\prime \prime}+v^{\prime}>v^{C}$ ). This means that for all loan amounts $L$, the bank's debt claim under traditio is no greater than that under contract and becomes strictly less as the loan amount increases. The debt claims are solved for in Eqs. (1) and (3) and illustrated in Fig. 2. Another way of looking at it is that the bank's interest rate (measured as $\left[\left(D^{j} / L\right)-1\right]$ ) is (weakly) less under traditio than under contract, with the inequality being strict for loans that have a positive risk of default. Whatever additional value the bank receives in the traditio regime from an insolvent firm, it gives up in its collection through its interest rate for that firm.

The behaviour of the advance purchase price, on the other hand, is opposite to that of the interest rate on the loan. Without any risk of a loan default in either regime, we have $v^{C}=v^{T}$. Whenever there is a risk of loan default, the traditio regime differs from the contract regime in that $v^{C}>v^{T}$. This is illustrated in Fig. 3.

Results 1 and 4 show that the priority regime, if known at the time of contracting, has no impact. This is because contracting parties internalise the economic consequences of the regime when taking ex ante decisions. However, as discussed in Sect. 2, some lawyers argue that, compared to the contract regime, the traditio regime prevents fraud more effectively. How do we consider this aspect of the lawyers' argument in our economic analysis?

In our model, we have assumed that the advance buyer is an independent agent and not related in any way to the entrepreneur. In practice, however, the advance buyer could become endogenous to the system. It is reasonable to assume that the firm-insiders would have greater knowledge about project's success probabilities. For instance, if the entrepreneur knows that a project will fail before it actually does, she may make a deal with a 'related party' to pose as an advance buyer. This buyer and the entrepreneur can settle on an official price $v_{0}<v^{C}$, transfer $v_{0}$ to the bank when the project fails, and share the surplus $v^{C}-v_{0}$. Observe that this is not possible under the traditio regime because the bank has the first claim on all the value of a failed firm.

First, observe that in our model, the advance buyer is (often) contracting to buy a product that has a value higher than what the market is willing to pay. Consequently, this price is an outcome of the relative bargaining capabilities of the two partiesthe project decision-maker and the buyer. These bargaining strengths are unobservable. Second, the project usually has information on impending insolvency before the creditor. In this situation, it is possible for the project to enter into a contract with related parties to sell products through the advance purchase mechanism.

'Asset stripping' under impending insolvency is well recognised in the literature. Indeed, legal codes in countries that otherwise follow the contract regime specifically enable bankruptcy officials to identify and nullify such agreements or cancel the suspect sales that may have been made prior to bankruptcy (see Sect. 2, and e.g. Mouial-Bassilana 2016). In reality, it is difficult to identify such agreements

\footnotetext{
$\overline{43}$ See the paragraph immediately before Result 3 .
} 
by simply looking at the price set in the agreement. For example, if $v^{C} \geq v^{\prime}$, it is difficult for a bankruptcy official to claim fraud. Moreover, post customisation, the market value may actually be lower than $m$ (the cost of customisation). On the other hand, if $v^{0}>m \geq v^{\prime}$ and one is in a contract regime, it may be better for the creditor to honour the contract and collect the $v^{0}$ even though the unobserved $v^{C}$ could be well above $v^{0}$. Under traditio, such a situation is irrelevant since $v^{T}+v^{\prime}>v^{C}$ regardless of how they compare with $m$.

\section{Conclusion}

This study investigated the economic consequences of two opposing regimes-traditio and contract - applied by legislators in different jurisdictions. Our results suggest that the two regimes are equivalent in terms of the net utilities enjoyed by each player, namely, the entrepreneur, the bank, and the advance buyer. We also found that the higher prices of the advance purchase products in the traditio regime can be compensated by better credit terms. An interesting policy implication is that there is no competitive advantage for either the seller or buyer in a contract regime compared to a traditio regime. Earlier analyses have incorrectly used market prices to determine the advantage of each regime, which may be misleading and biased towards the contract regime. A more accurate method is to compare the initial decisions to invest, which, in our analysis, are equivalent in both regimes.

The second policy implication refers to the possibility of fraud. The traditio regime should be preferred if there is a weak enforcement of corporate governance, i.e. when we relax the assumption that the creditor and the buyer are independent, and instead concur that the creditor has prior knowledge about a possible project failure, but the bank does not. Such fraudulent behaviour is not feasible under a traditio regime. Revealing fraud in a contract regime by comparing the negotiated prices and market prices is challenging when the bargaining strengths of each party and the degree of product customisation made for the buyer are unknowns.

Our conclusions regarding the preferable principle are based on a question of who should be given priority between two different parties-the advance buyers and the other creditors. Our result, showing equality between the two regimes, is supported empirically by the fact that neither regime dominates the other when considering the choices of different countries. For example, competing, but very similar neighbouring countries such as Sweden and Finland, can use different principles without either of them having an economic disadvantage over the other. Since we conclude that the two regimes are equivalent, it is not strange that different countries have made different choices. As we have pointed out (in Sect. 2), there are also other aspects to consider in the choice of principle. The choice is to some degree dependent on the legal systematic aspects. These aspects vary between legal systems and jurisdictions. The fact that one jurisdiction can use both principles for different circumstances can be viewed from this perspective. It is also possible that in most jurisdictions using the traditio principle, it is allowed and common for the parties, and some branches of industry, to depart from the 


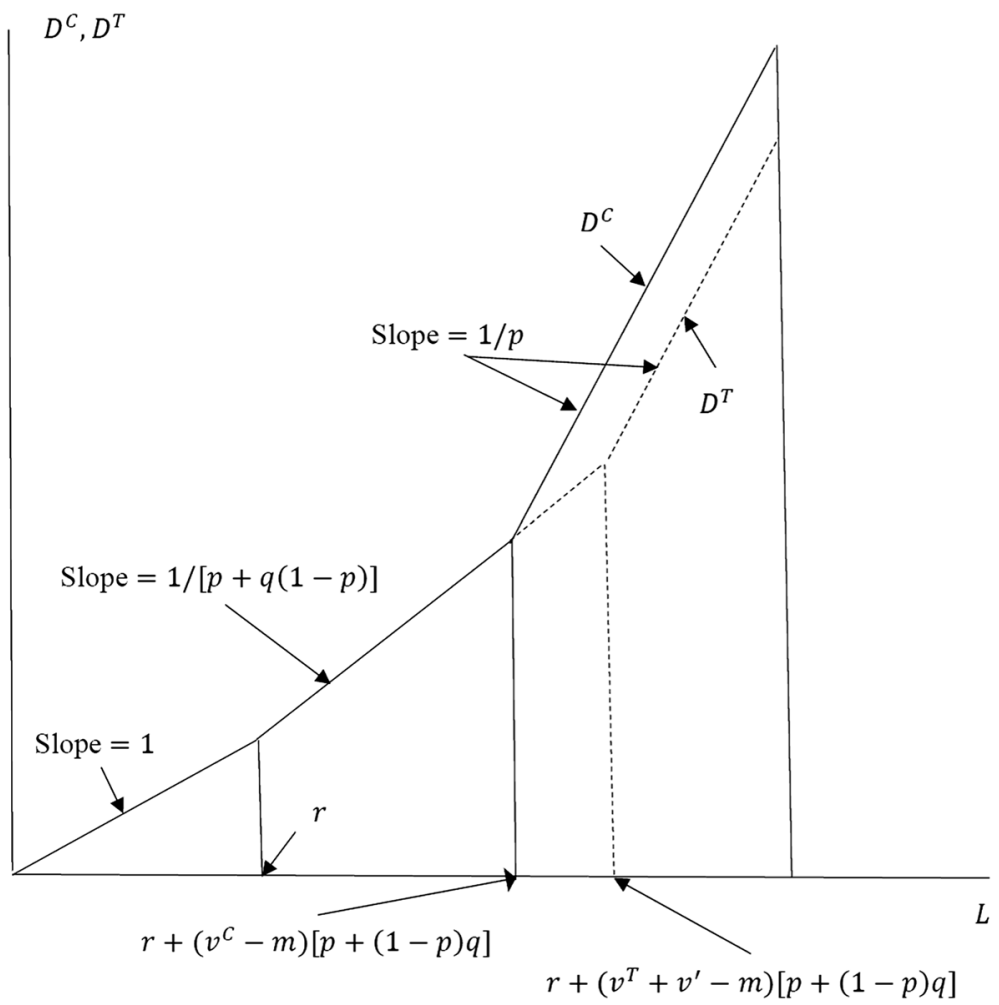

Fig. 2 Debt claims and loan amounts under the contract and traditio regime. From Eq. (2) in the text, $v^{c}<v^{T}+v^{\prime}$ because the maximum value of the right hand side of Eq. (2) is $v^{T}+(1-p) v^{\prime}=v^{T}+v^{\prime}-p v^{\prime}<v^{T}+v^{\prime}$. Hence, $r+\left(v^{T}+v^{\prime}-m\right)[p+(1-p) q]>r+\left(v^{c}-m\right)[p+(1-p) q]$. The slopes are calculated from the expressions $D^{C}$ and $D^{T}$ given in Eqs. (1) and (3), respectively

traditio requirement and agree to apply the contract regime when it seems to suit the situation better.

Funding Open access funding provided by University of Gothenburg.

Open Access This article is licensed under a Creative Commons Attribution 4.0 International License, which permits use, sharing, adaptation, distribution and reproduction in any medium or format, as long as you give appropriate credit to the original author(s) and the source, provide a link to the Creative Commons licence, and indicate if changes were made. The images or other third party material in this article are included in the article's Creative Commons licence, unless indicated otherwise in a credit line to the material. If material is not included in the article's Creative Commons licence and your intended use is not permitted by statutory regulation or exceeds the permitted use, you will need to obtain permission directly from the copyright holder. To view a copy of this licence, visit http://creativecommons.org/licen ses/by/4.0/. 


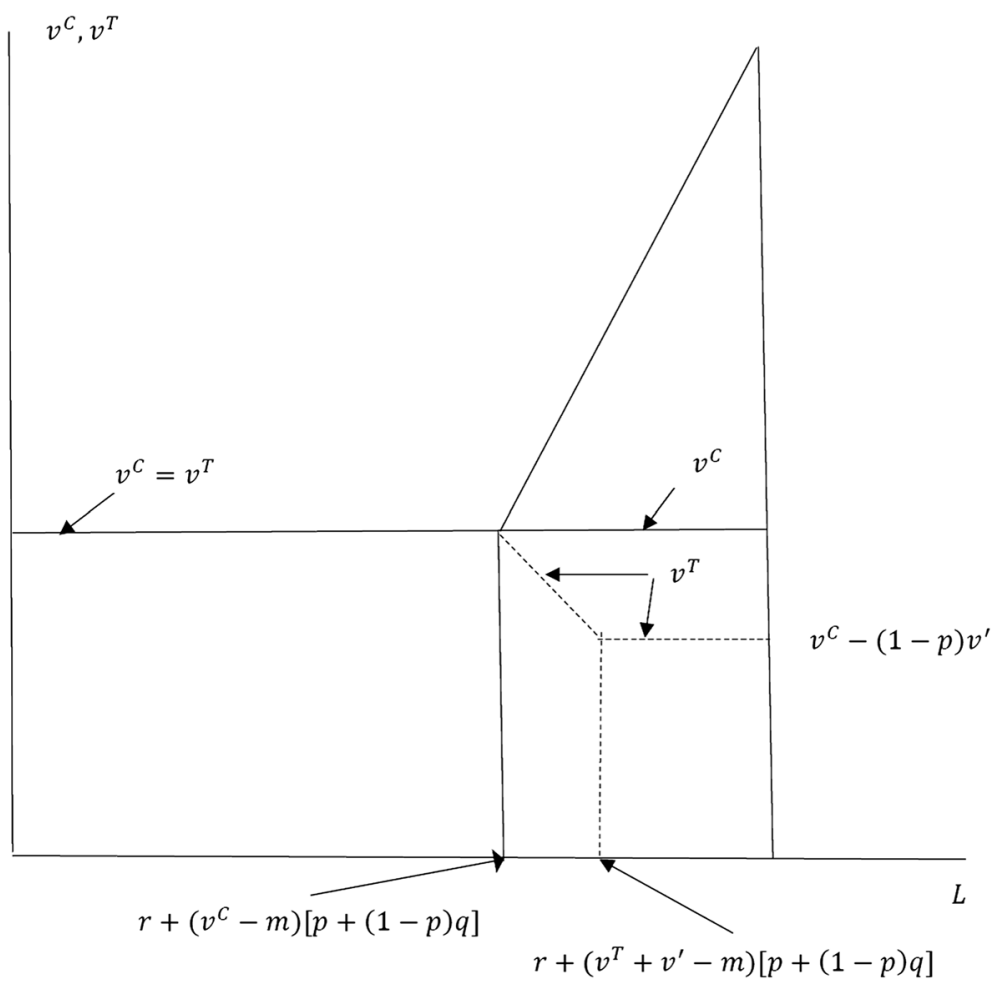

Fig. 3 Advance product prices and loan amounts under contract and traditio regimes. From Eq. (2) in the text, $v^{c}<v^{T}+v^{\prime}$ because the maximum value of the right hand side of Eq. (2) is $v^{T}+(1-p) v^{\prime}=v^{T}+v^{\prime}-p v^{\prime}<v^{T}+v^{\prime}$. Hence, $r+\left(v^{T}+v^{\prime}-m\right)[p+(1-p) q]>r+\left(v^{c}-m\right)[p+(1-p) q]$. Also, when we have $L \geq r+\left(v^{T}+v^{\prime}-m\right)[p+(1-p) q]$, we know that $D^{T} \geq\left(r-m+v^{T}+v^{\prime}\right)$ and this implies that $\left[\min \left[v^{\prime}, \max \left\{D^{T}-\left(r-m+v^{T}\right), 0\right\}\right]\right]=v^{\prime}$ giving us $v^{C}=v^{T}+(1-p) v^{\prime}$

\section{Appendix}

Proof of Result 1 The fact that $\Omega^{C}=v^{\prime \prime}-v^{C}$ is immediate and follows from the paragraph preceding the statement of Result 1 in the text. $\Gamma^{C}=0$ follows from the assumptions that the bank is competitive, risk neutral and makes zero (abnormal) profit. The bank's net surplus is given by

$$
\Gamma^{C}=p(1-q) D^{C}+p q D^{C}+(1-p)(1-q) \min \left\{r, D^{C}\right\}+q(1-p) \min \left\{r-m+v^{C}, D^{C}\right\}-L
$$

Net return to equity is given by 


$$
\begin{aligned}
\Pi^{C}= & p(1-q)\left(R-D^{C}\right)+p q\left(R-m+v^{C}-D^{C}\right)+(1-p)(1-q) \max \left\{r-D^{C}, 0\right\} \\
& +q(1-p) \max \left\{r-m+v^{C}-D^{C}, 0\right\}-A
\end{aligned}
$$

With probability $(1-q)$, the advance buyer will not come and then, the entrepreneur gets $R-D^{C}$ if the project is successful, which happens with probability $p$. With probability $(1-p)$, the project fails and then equity gets a return only if there is anything left over after the bank is repaid. In the presence of the advance buyer, that happens with probability $q$, a successful project has, at the end of Stage 2, an amount equal to $R-m+v^{C}$, while the unsuccessful project has $r-m+v^{C}$.

Using $\max \{a-b, 0\}=a-\min \{a, b\}$, we can write

$$
\begin{aligned}
\Pi^{C}= & p R+p q\left(v^{C}-m\right)+(1-p)(1-q)\left[r-\min \left\{r, D^{C}\right\}\right] \\
& +q(1-p)\left[r-m+v^{C}-\min \left\{r-m+v^{C}, D^{C}\right\}-p D^{C}-(I-L)\right. \\
= & p R+(1-p)(1-q) r+q(1-p)\left(r-m+v^{C}\right)+p q\left(v^{C}-m\right)-I \\
& -\left[p D^{C}+(1-p)(1-q) \min \left\{r, D^{C}\right\}+q(1-p) \min \left\{r-m+v^{C}, D^{C}\right\}-L\right]
\end{aligned}
$$

The second line of the last expression in square brackets is nothing but the net return to the bank from the project, $\Gamma^{C}$, and this is equal to zero. So,

$$
\begin{aligned}
\Pi^{C} & =p R+(1-p)(1-q) r+q(1-p)\left(r-m+v^{C}\right)+p q\left(v^{C}-m\right)-I \\
& =[p R+(1-p) r-I]+q\left(v^{C}-m\right)
\end{aligned}
$$

Proof of Result 2 The bank's return is

$\Gamma^{C}=p D^{C}+(1-p)(1-q) \min \left\{r, D^{C}\right\}+q(1-p) \min \left\{r-m+v^{C}, D^{C}\right\}-L$

(a) If $\min \left\{r, D^{C}\right\}=D^{C}$, then, so is $\min \left\{r-m+v^{C}, D^{C}\right\}=D^{C}$. Then, $\Gamma^{C}$ is equal to

$$
p D^{C}+(1-p)(1-q) D^{C}+q(1-p) D^{C}-L=D^{C}-L
$$

Setting this equal to zero, gives us $D^{C}=L$ for $L \leq r$.

(b) Now, let $r<D^{C}$ but $D^{C} \leq r-m+v^{C}$. Now $\Gamma^{C}$ is equal to

$$
p D^{C}+(1-p)(1-q) r+q(1-p) D^{C}-L
$$

Setting this equal to zero, we get

$$
D^{C}=\frac{L-(1-p)(1-q) r}{p+(1-p) q}
$$

Using the fact that $r<D^{C} \leq r-m+v^{C}$ we get the relevant range of $L$. 
(c) When $D^{C}>r-m+v^{C}$, we have $\Gamma^{C}$ equal to

$$
p D^{C}+(1-p)(1-q) r+q(1-p)\left(r-m+v^{C}\right)-L
$$

Since this expression is equal to zero, we get

$$
D^{C}=\frac{L-(1-p)(1-q) r-(1-p) q\left(r+v^{C}-m\right)}{p}
$$

The range for $L$ is obtained by noting that $D^{C}>r-m+v^{C}$ implies that

$$
\frac{L-(1-p)(1-q) r-(1-p) q\left(r+v^{C}-m\right)}{p}>r-m+v^{C}
$$

This gives us the lower limit of $L$ and, we know that $L \leq I$.

Proof of Result 3 The bank's return in the traditio regime is

$$
\Gamma^{T}=p D^{T}+(1-p)(1-q) \min \left\{r, D^{T}\right\}+q(1-p) \min \left\{r-m+v^{T}+v^{\prime}, D^{T}\right\}-L
$$

(a) If $\min \left\{r, D^{T}\right\}=D^{T}$, then, so is $\min \left\{r-m+v^{T}+v^{\prime}, D^{T}\right\}=D^{T}$. Then, $\Gamma^{T}$ is equal to

$$
p D^{T}+(1-p)(1-q) D^{T}+q(1-p) D^{T}-L=D^{T}-L
$$

Setting this equal to zero, gives us $D^{T}=L$ for $L \leq r$.

(b) Now, let $r<D^{T}$ but $D^{T} \leq r-m+v^{T}+v^{\prime}$. Now $\Gamma^{T}$ is equal to

$$
p D^{T}+(1-p)(1-q) r+q(1-p) D^{T}-L
$$

Setting this equal to zero, we get

$$
D^{T}=\frac{L-(1-p)(1-q) r}{p+(1-p) q}
$$

Using the fact that $r<D^{T} \leq r-m+v^{T}+v^{\prime}$ we get the relevant range of $L$.

(c) When $D^{T}>r-m+v^{T}+v^{\prime}$, we have $\Gamma^{T}$ equal to

$$
p D^{T}+(1-p)(1-q) r+q(1-p)\left(r-m+v^{T}+v^{\prime}\right)-L
$$

Since this expression is equal to zero, we get 


$$
D^{T}=\frac{L-(1-p)(1-q) r-(1-p) q\left(r+v^{T}+v^{\prime}-m\right)}{p}
$$

The range for $L$ is obtained by noting that $D^{T}>r-m+v^{T}+v^{\prime}$ implies that

$$
\frac{L-(1-p)(1-q) r-(1-p) q\left(r+v^{T}+v^{\prime}-m\right)}{p}>r-m+v^{T}+v^{\prime}
$$

In this regime too, $L \leq I$.

Proof of Result 4 The bank's net surplus is given by

$$
\Gamma^{T}=p(1-q) D^{T}+p q D^{T}+(1-p)(1-q) \min \left\{r, D^{T}\right\}+q(1-p) \min \left\{r-m+v^{T}+v^{\prime}, D^{T}\right\}-L
$$

Net return to equity is given by

$$
\begin{aligned}
\Pi^{T}= & p(1-q)\left(R-D^{T}\right)+p q\left(R-m+v^{T}-D^{T}\right)+(1-p)(1-q) \max \left\{r-D^{T}, 0\right\} \\
& +q(1-p) \max \left\{r-m+v^{T}-D^{T}, 0\right\}-A
\end{aligned}
$$

Observe that in the traditio regime, $v^{\prime}$ does not directly enter equity returns. It enters through the valuation of the debt when the project fails. The fact that the lender can seize the undelivered product under default gives the bank greater value than just $r-m+v^{T}$. This additional $v^{\prime}$ value, however, is distributed between the bank and the advance buyer; the

(a) When $L \leq r$, there is no default as $D^{T}=L$ allows the lender to be paid in full in all states. This also means that the advance buyer always gets her product and so $v^{T}=v^{C}$. Thus

$$
\begin{aligned}
\Pi^{T}= & p(R-L)+p q\left(v^{T}-m\right)+(1-p)(1-q)(r-L) \\
& +q(1-p)\left\{r-m+v^{T}-L\right\}-(I-L) \\
= & p R+(1-p) r-I+q\left(v^{C}-m\right)=\Pi^{C}
\end{aligned}
$$

(b) When $r<L \leq r+\left(v^{T}+v^{\prime}-m\right)[p+(1-p) q]$ there are two sub-cases to consider.

Case $1 r<L \leq r+\left(v^{T}-m\right)[p+(1-p) q]$

We claim that this corresponds to $r<D^{T} \leq r-m+v^{T}$. This would imply

$$
\Gamma^{T}=p D^{T}+(1-p)(1-q) r+q(1-p) D^{T}-L
$$

Setting $\Gamma^{T}=0$, gives us $D^{T}=[L-(1-p)(1-q) r] /[p+q(1-p)]$. Since, by hypothesis, $r<D^{T} \leq r-m+v^{T}$, plugging in the value od $D^{T}$ gives us the range for $L$ in this case. 
Here, the advance price enables the lender to get fully repaid without having to put the undelivered product on the market. In other words, the advance buyer always gets her product and so $v^{C}=v^{T}$.

So,

$$
\begin{aligned}
\Pi^{T} & =p\left(R-D^{T}\right)+p q\left(v^{T}-m\right)+q(1-p)\left(r-m+v^{T}-D^{T}\right)-A \\
& =p R+p q\left(v^{T}-m\right)+q(1-p)\left(r-m+v^{T}\right)-[p+(1-p) q] D^{T}-A
\end{aligned}
$$

Plugging in the value of $D^{T}$ and, recalling that $A=I-L$ and $v^{T}=v^{C}$, we have equity return to be $\Pi^{T}=p R+(1-p) r-I+q\left(v^{C}-m\right)=\Pi^{C}$

Case $2 r<r+\left(v^{T}-m\right)[p+(1-p) q]<L \leq r+\left(v^{T}+v^{\prime}-m\right)[p+(1-p) q]$

We claim that this corresponds to $r-m+v^{T}<D^{T} \leq r-m+v^{T}+v^{\prime}$. The lender continues to be fully repaid in the presence of the advance buyer, so

$$
\Gamma^{T}=p D^{T}+(1-p)(1-q) r+q(1-p) D^{T}-L
$$

Setting $\Gamma^{T}=0$, gives us $D^{T}=[L-(1-p)(1-q) r] /[p+q(1-p)]$. Since, by hypothesis, $r-m+v^{T}<D^{T} \leq r-m+v^{T}+v^{\prime}$, plugging in the value od $D^{T}$ gives us the range for $L$ in this case.

In this case, equity gets nothing when the project fails, with or without the advance buyer, giving us

$$
\Pi^{T}=p\left(R-D^{T}\right)+p q\left(v^{T}-m\right)-A=p R+p q\left(v^{T}-m\right)-p D^{T}-A
$$

We now go back to Eq. (2) in the text.

$$
v^{C}=v^{T}+(1-p)\left[\min \left[v^{\prime}, \max \left\{D^{T}-\left(r-m+v^{T}\right), 0\right\}\right]\right]
$$

Given the range of $D^{T}$, we know that

$$
\begin{aligned}
& v^{C}=v^{T}+(1-p)\left[D^{T}-\left(r-m+v^{T}\right)\right]=p v^{T}+(1-p)\left[D^{T}-(r-m)\right] \\
& v^{T}=\frac{v^{C}}{p}-\frac{(1-p)\left[D^{T}-(r-m)\right]}{p}
\end{aligned}
$$

Plugging this value into the expression for $\Pi^{T}$, we get

$$
\begin{aligned}
\Pi^{T} & =p R+q\left(v^{C}-m\right)-q(1-p) D^{T}+q(1-p) r-p D^{T}-A \\
& =p R+q\left(v^{C}-m\right)+q(1-p) r-[p+q(1-p)] D^{T}
\end{aligned}
$$

Plugging in the value of $D^{T}$, we get $\Pi^{T}=p R+(1-p) r-I+q\left(v^{C}-m\right)=\Pi^{C}$.

(c) Finally, we consider $r+\left(v^{T}+v^{\prime}-m\right)[p+(1-p) q]<L \leq I$.

We claim that this corresponds to $D^{T}>r-m+v^{T}+v^{\prime}$. The lender now gets 


$$
\Gamma^{T}=p D^{T}+(1-p)(1-q) r+q(1-p)\left(r-m+v^{T}+v^{\prime}\right)-L
$$

Setting $\Gamma^{T}=0$, gives us $D^{T}=\left[L-(1-p)(1-q) r-q(1-p)\left(r-m+v^{T}+v^{\prime}\right] /[p]\right.$. Since, by hypothesis, $D^{T}>r-m+v^{T}+v^{\prime}$, plugging in the value od $D^{T}$ gives us the range for $L$ in this case, noting that $L$ cannot be greater than $I$.

Once again, equity gets nothing when the project fails, with or without the advance buyer, giving us

$$
\Pi^{T}=p\left(R-D^{T}\right)+p q\left(v^{T}-m\right)-A=p R+p q\left(v^{T}-m\right)-p D^{T}-A
$$

From Eq. (2) in the text and given the range of $D^{T}$, we get

$$
v^{C}=v^{T}+(1-p) v^{\prime} \Leftrightarrow v^{T}=v^{C}-(1-p) v^{\prime}
$$

Plugging this value into the expression for $\Pi^{T}$, we get

$$
\Pi^{T}=p R+p q\left(v^{C}-m\right)-p q(1-p) v^{\prime}-p D^{T}-A
$$

Plugging in the value of $D^{T}$, we get $\Pi^{T}=p R+(1-p) r-I+q\left(v^{C}-m\right)=\Pi^{C}$.

\section{References}

Altman, E. (1984). A further empirical investigation of the bankruptcy cost question. Journal of Finance, 39(4), 1067-1089.

Altman, E. (1993). Corporate financial distress and bankruptcy (2nd ed.). New York: Wiley.

Andreasson, J., Faber, W., Gangopadhyay, S., Martinson, C., \& Sjögren, S. (2015). Prioritet för köpare en fråga om tradition eller princip? Svensk Juristtidning, 9, 709-748.

Baird, D. G. (2017). Priority matters: Absolute priority, relative priority, and the costs of bankruptcy. University of Pennsylvania Law Review, 165(4), 785-830.

Baird, D. G., \& Jackson, T. H. (1984). Corporate reorganization and the treatment of diverse ownership interests: A comment on adequate protection of secrued creditors in bankruptcy. University of Chicago Law Review, 51(1), 97-130.

Bebchcuk, L. A., \& Fried, J. (1996). The uneasy case for the priority of secured claims in bankruptcy. Yale Law Journal, 105, 857-934.

Bergström, C., Eisenberg, T., \& Sundgren, S. (2004). On the design of efficient priority rules for secured creditors: empirical evidence from a change in law. European Journal of Law and Economics, 18, $273-297$.

Bernstein, S., Colonnelli, E., \& Iverson, B. (2018). Asset allocation in bancruptcy. Journal of Finance, 74(1), 5-53.

Brækhus, S. (1988). Omsetning og kreditt $3 \mathrm{og}$ 4, Omsetningskollisjoner I og II. Oslo: Universitetsforlaget.

Branch, B. (2002). The costs of bankruptcy: a review. International Review of Financial Analysis, 11(1), 39-57.

Bris, A., Welch, I., \& Zhu, N. (2006). The costs of bankruptcy: chapter 7 liquidation versus chapter 11 reorganization. The Journal of Finance, 61(3), 1253-1303.

Bucher, E. (1998). Die Eigentums-Translativwirkung von Schuldverträgen: Das „Woher“ und „Wohin“ dieses Modells des Code Civil, ZEuP (Zeitschrift für europäisches Privatrecht). Munich: C.H Beck.

Casey, A. J. (2019). Chapter 11's renegotiation Framework and the purpose of Corproate Bankruptcy, Columbia Law Review, Forthcoming.

Cerqueiro, G., Ongena, S., \& Roszbach, K. (2016) Collateral damage? On collateral, corporate financing and performance. ECB Working paper. No 1918.

Dedek, H. (2018). Article 6:103: Simulation. In Nils Jansen \& Reinhard Zimmermann (Eds.), Commentaries on European contract laws (pp. 814-819). Oxford: Oxford University Press.

Delson, M. G. (2000). Philippines, International Encyclopaedia of Law, Property and Trust Law, 2, Wolters Kluwer. 
Faber, W. (2008). Zur Übereignung nach dem tschechischen Entwurf eines Zivilgesetzbuches von 2005 - Anmerkungen aus rechtsvergleichender Sicht. In Jiří Švestka, Jan Dvořák, \& Luboš Tichý (Eds.), Sborník statí z diskusních fór o rekodifikaci občanského práva-Tagungsband der Diskussionsforen zum Bürgerlichen Gesetzbuch, 40. Praha: Wolters Kluwer.

Faber, W. (2010). Overview of content and methodology: Book VIII of the DCFR". The Edinburgh Law Review, 14(3), 499-504.

Faber, W., \& Lilja, M. (2012). Argumentation analysis in the discussion of optimal rules for the transfer of movables-Part 2: Examples and conclusions. European Property Law Journal, 1(2), 232-298.

Faber, W., Lilja, M., \& Kreuzbauer, G. (2012). Employing argumentation analysis in the discussion of optimal rules for the transfer of movables-Part 1: description of the problem and general outline. European Property Law Journal, 1(1), 10-53.

Faber, W. \& Lurger, B. (2008-2011). National Reports on the Transfer of Movables in Europe, volumes I-VI, Sellier European law publisher.

Faber, W., \& Martinson, C. (2019). Can ownership limit the effectiveness of EU consumer contract law directives? A suggestion to employ a 'functional approach'. Austrian Law Journal, 1, 85-123.

Franks, J. R., \& Torous, W. N. (1994). A comparison of financial recontracting in distressed exchanges and chapter 11 reorganizations. Journal of Financial Economics, 35(3), 349-370.

Göransson, U. (1985). Traditionsprincipen - de svenska reglerna om köparens skydd mot säljarens borgenärer i komparativ och historisk belysning. Uppsala: Iustus.

Graver, H. P. (1986). Den juristskapte virkelighet. Oslo: Tano.

Håstad, T. (2009). Derivative transfer of ownership of goods. European Review of Private Law, 4, 725-741.

Håstad, T. (1996). Sakrätt avseende lös egendom, 6th edn, Stockholm, Norstedts

Henriksson, P. (2009). Sakrättsliga moment, och deras ekonomiska konsekvenser. Stockholm: Jure.

Henriksson, P. (2015). En rättsekonomisk analysmodell vid utvärderingen av ett slopat traditionskrav vid överlåtelse av lösöre, Rapport till Lösöreköpskommittén, Ju2013:05. Published in SOU 2015:18 p. 237-272.

Hessler, H. (1973). Allmän Sakrätt. Stockholm: Norstedts.

Hortacsu, A., Matvos, G., Syverson, C., \& Wenkataraman, S. (2013). Costs of financial distress in durable goods industries: The case of auto manufacturers. Review of Financial Studies, 26(5), 1248-1290.

Hotchkiss, E. S. (1995). Postbankruptcy performance and management turnover. Journal of Finance, $50(1), 3-21$.

Hotchkiss, E. S., Kose, J., Mooradian, R. M., \& Thorburn, K. S. (2007). Bankruptcy and the resolution of financial distress. In B. E. Eckbo (Ed.), Handbook of corporate finance: Empirical corporate finance (Vol. 2). Amsterdam: Elsevier/North-Holland.

Jackson, T. G. (1982). Bankruptcy, non-bankruptcy entitlements, and the creditors' bargain. Yale Law Journal, 91(5), 857-860.

Kale, J. R., \& Shahrur, H. (2007). Corporate capital structure and the characteristics of suppliers and customers. Journal of Financial Economics, 83, 321-365.

Lilja, M. (2014). The relevance of concepts for the transfer of movables under the uniform commercial code-With a focus on the buyer's protection against the seller's creditors. European Property Law Journal, 3, 54-64.

Llewellyn, K. (1938). Through title to contract and a bit beyond. N.Y.U. L.Q. Rev. 159, 15, 169.

Lohsse, S., \& Jin, J. (2015). Sachenrecht: Begrifflichkeiten, Prinzipien, Eigentum. In J. Binding, K. B. Pißler, \& L. Xu (Eds.), Chinesisches Zivil- und Wirtschaftsrecht. Frankfurt am Main: Fachmedien Recht und Wirtschaft in Deutscher Fachverlag.

Lurger, B., \& Faber, W. (2011). Principles of European law: Acquisition and loss of ownership of goods (PEL Acq. Own.). München: Sellier European Law Publisher.

Maksimovics, V., \& Phillips, G. (1998). Asset efficiency and reallocation decision of bankrupt firms. Journal of Finance, 53(5), 1495-1532.

Martinson, C. (2002). Kreditsäkerhet I fakturafordringar, En förmögenhetsrättslig studie. Uppsala: Iustus.

Martinson, C. (2006). Transfer of title concerning movables part III. Frankfurt a.M: Peter Lang.

McBryde, W., Flessner, A., \& Kortmann, S. (2003). Principles of European insolvency law. Philadelphia: Kluwer.

McGuire, M.-R. (2006). Ziel und Methode der Study Group on a European Civil Code. Zeitschrift für Europarecht, internationals Privatrecht und Rechtsvergleichung, p. 163. 
Meijers, E. M. (1936). Eigendomsoverdracht tot zekerheid - preadvis Broederschap der notarissen. Correspondentieblad van de Broederschap der notarissen 39, 1957; reprint in Feenstra/Fischer/Blok/ Wubbe (Hrsg), Bibliographie der geschriften van E. M. Meijers, 250.

Mellqvist, M. (2010) Diocletianus vs. Grotius — om den sakrättsliga traditionsprincipens berättigande. Svensk Juristtidning. 217-244.

Mouial-Bassilana, E. (2016). Précisions autour des nullités de la période suspecte: obs. sous Cass. com., 18 juin 2016, $\mathrm{n}^{\circ}$ 14-24910, F-PB.

Myrdal, S. (2002). Borgenärsskyddet: Om principerna för skyddet mot överlåtarens och pantsättarens borgenärer. Stockholm: Norstedts Juridik.

Pietrek, M. (2015). Konsens über Tradition? Eine Studie zur Eigentumsübertragung in Brasilien, Deutschland und Portugal. Max-Planck-Institut, Studien zum ausländischen und internationalen Privatrecht 328, Mohr Siebeck.

Pulvino, T. C. (1998). Do asset fire sales exist? An empirical investigation of commercial aircraft transactions. The Journal of Finance, 53(3), 939-978.

Pulvino, T. C. (1999). Effects of bankruptcy court protection on asset sales. Journal of Financial Economics, 52(2), 151-186.

Ross, A. (1956-57). Tû-Tû. Harvard aw Review, 70, 812-825.

Rumpf, C. (2004). Einführung in das türkische Recht. Schriftenreihe der Juristische Schulung: Ausländisches Recht, 169, Beck.

Sacco, R. (2009). A comparative analysis: The contractual transfer of ownership of movable property. In M. Bussani \& F. Werro (Eds.), European private law: A handbook, Volume I, 89.

Sagaert, V. (2008). Consensual versus deliver systems in European Private Law-Consensus about tradition. In W. Faber \& B. Lurger (Eds.), Rules for the transfer of movables, a candidate for European harmonisation or national reforms. Munich: Sellier.

Sagaert, V., \& del Corral, J. (2012). Acquisition of Ownership of Goods in the DCFR: A Belgian Perspective. In V. Sagaert, M. Storme \& E. Terryn (Eds.), The DCFR from a national and comparative perspective, 343.

Schleifer, A., \& Vishny, R. W. (1992). Liquidiation values and debt capacisty: A market equilibrium approach. Journal of Finance, 47(4), 1343-1364.

SOU 1995:11 Nya konsumentregler, Justitiedepartementet, Stockholm.

SOU 2015:18 Lösöreköp och registerpant. Justitiedepartementet, Stockholm.

Stadler, A. (2010). Die Vorschläge des Gemeinsamen Referenzrahmens für ein europäisches Sachenrecht - Grundprinzipien und Eigentumsübertragung. Juristenzeitung, 380.

Stagl, J. (2015). Eigentumsübertragung beim Kauf beweglicher Sachen im DCFR und im CESL. RabelsZ $79(1)$.

Süß, T. (1952). Das Traditionsprinzip - Ein Atavismus des Sachenrechts, in Festschrift für Martin Wolf, 141.

The Law Commission. (2002). Registration of security interests: Company charges and Property other than Land. London, Consultation Paper No 164.

Twining, W. (2012). Karl Llewellyn and the realist movement (2nd ed.). Cambridge: Cambridge University Press.

van Erp, S., \& Akkermans, B. (2012). Cases, materials and text on national, supranational and international property law. Oxford: Hart Publishing.

van Vliet, L. (2000). Transfer of movables in German, French, English and Dutch law. Libri.

von Bar, C. (2019). Gemeineuropäisches Sachenrecht, volume II, Besitz; Erwerb und Schutz subjektiver Sachenrechte. Munich: C.H. Beck.

von Bar, C., \& Clive, E. (2010). Prepared by the Study Group on a European Civil Code and the Research Group on EC private Law (Acquis Group), principles, definitions and model rules of European Private Law-Draft Common Frame of Reference (DCFR) full edition. Oxford: Oxford University Press.

Walczak, D. (2017). Die Eigentumsübertragung beim Kauf beweglicher Sachen nach dem DCFR (2017). Rechtsvergleichung und Rechtsvereinheitlichung. XIV, 89-124.

Wiegand, W. (2000). Die Entwicklung der Übereignungstatbestände einschließlich der Sicherungsübereignung. In C.-W. Canaris \& A. Heldrich et al (Eds.), 50 Jahre Bundesgerichtshof - Festgabe aus der Wissenschaft.

Windscheid, B. \& Kipp, T. (1906). Lehrbuch des Pandektenrechts (9th ed, Vol. I). 
Wood, P. R. (2006). Publicity for transfers of property: Is the whole world out of step (except New Zealand)? In Festschrift für Norbert Horn, 191.

Zufall, F. (2010). Das Abstraktionsprinzip im japanischen Zivilrecht. ZjapanR, 15.

Publisher's Note Springer Nature remains neutral with regard to jurisdictional claims in published maps and institutional affiliations. 